\title{
Nuclear Receptor Coactivator 5
}

National Cancer Institute

\section{Source}

National Cancer Institute. Nuclear Receptor Coactivator 5. NCI Thesaurus. Code C33996.

Nuclear receptor coactivator 5 ( $614 \mathrm{aa}, \sim 70 \mathrm{kDa}$ ) is encoded by the human NCOA5 gene.

This protein is involved in the regulation of nuclear receptor-mediated gene transcription. 